\title{
Towards a Female Topography of the Ancient Greek City: Case Studies from Late Archaic and Early Classical Athens (c.520-400 BCE)
}

\author{
Lisa C. Nevett
}

Traditionally, scholars assumed that the proper domain for respectable Greek women lay in the domestic sphere, largely closeted within the walls of the house itself. In contrast, the city's wider, civic arena was viewed as belonging to its male citizens. This model reflects the dominant view articulated explicitly in many of the surviving written sources. But it is based on the writings of a small number of elite men; it also relies on texts which were composed for limited audiences and with specific goals in mind. For this reason, the extent to which the model can be taken as a literal representation of actual behaviour and, even if it can, the proportion of women who would have observed these ideals, have since been questioned. ${ }^{1}$

My goal in this article is to explore how far, in the absence of direct written testimony from Classical Greek women themselves, it is possible to reconstruct a female topography of an ancient Greek city. One possible approach to studying gendered space in Greek cities would be to examine the tension between the ideology and perspectives of the adult male citizen, as materialised in civic and religious spaces, and the perspectives of women, as experienced through the organisation of households. ${ }^{2}$ Nonetheless, to take such an approach would be to oversimplify the problem by framing the inquiry within the elite, male, textual construction of the two spheres as opposed and differently gendered, a strategy which would, at the very least, fail to do justice to the complexities of social life as they have already begun to emerge through recent scholarship.

As is becoming increasingly clear, the domestic sphere was not, in fact, exclusively a female preserve: on the contrary, it played an important role for male citizens, both as a status symbol and as an arena for entertaining friends and associates, particularly at the symposium or drinking party. ${ }^{3}$ By the same token, a number of scholars have recently highlighted the fact that some women played important roles outside the household in at least one sphere, that of civic cult. ${ }^{4}$ But while the latter studies have often seen religion as anomalous - an exception to a more generalised pattern of female isolation and powerlessness - here I argue that this view fails to differentiate between women's legal position, which disenfranchised them from direct, active participation in the political arena, and their physical and symbolic presence in the civic sphere. ${ }^{5}$ Therefore, following the lead of a number of social historians who have 
shown that women left their houses to participate in a variety of activities, in this paper I explore some of the contexts in which they may have been visible in the civic landscape of an ancient Greek city. ${ }^{6}$ I also seek to understand how their presence may have intersected with a range of variables including the passage of time, women's age and the socio-economic status of their families.

In contrast with a range of previous studies, which have highlighted evidence for female agency outside the domestic sphere with reference to the surviving texts, my main focus here is on the physical space of the Classical Greek city: although everything we know about architecture and town planning suggests that design and construction were in male hands, cross-cultural studies in a variety of contexts have shown that social landscapes, including patterns of gender associations, accrue through usage as well as resulting from the architectural design and layout of space. ${ }^{7}$ Traditionally, archaeologists studying ancient Greek cities have focused on aspects of their form and spatial organisation (such as the character and development of the urban plan) or on the architectural history and decorative details of individual buildings. While such studies have sometimes explored the possible symbolic significance of monumental structures and their decorative schemes, they have most often tended to reconstitute urban landscapes which are empty of their former inhabitants, setting aside questions about the way in which those landscapes originally functioned as social settings.

A few scholars have gone against this trend, attempting to connect the social and political structures of urban populations with the physical organisation of their built environments. The most ambitious such study, by Wolfram Hoepfner and ErnstLudwig Schwandner, argues that the democratic ethos of many Classical Greek cities was responsible for regular urban grid plans and for houses of similar size and layout which have been found as far apart as Piraeus (Attica), Olynthos (Greek Macedonia), Kassope (Epirus) and Priene (south-west Turkey). ${ }^{8}$ Hoepfner and Schwandner's work has had a mixed reception: the degree to which egalitarian ideals played such a direct and influential role in shaping these features has been doubted, and some of their reconstructions of individual city plans and buildings have been challenged. ${ }^{9}$ What has largely been overlooked, however, is that in highlighting the connection between architectural form and social life, the authors offer a radically different perspective on ancient architecture and town-planning. The implication of their work is that the form and use of space were intimately connected with the social processes by which that space was produced and reproduced - a belief widely shared by scholars working in a variety of other disciplines. $^{10}$

Against this background, I argue here for a less literal interpretation of the relationship of social and cultural influences to architectural form. I suggest that, instead of imposing a literary-based reading onto the material evidence, we can go a step further: the architectural spaces of the cities themselves can be used actively as a means to investigate aspects of the social lives of their inhabitants. Such an approach makes it possible to investigate those groups, including women, whose voices are not heard directly through the textual record.

In what precise ways can the presence and activities of women be traced in the civic spaces of Greek cities? This is obviously a large question, and I therefore offer here a brief treatment of a limited range of contexts in which I want to begin to attempt to clarify the extent and structuring of female activities. Work by archaeologists studying a variety of cultures has suggested that the most likely context in which the 
activities of subordinate social groups can be detected through the material record is in patterns of small-scale activity and short-term use. ${ }^{11}$ Here I focus on several activities of a cyclical nature which range in time-frame from daily or every few days, through annual, to every few years. My examples are: visits to friends' and relatives' houses; collection of water at public fountain houses; tending graves in cemeteries; and participation in religious processions. In each instance I try to reinstate some of the female users into parts of the urban landscape by drawing on a range of sources, including ceramic iconography, incidental references from surviving texts of various genres and behavioural parallels from comparative contexts. As a case-study I use evidence from late sixth- and fifth-century BCE Athens, a city for which evidence for the urban fabric is relatively well-documented, and for which we have an exceptionally large amount of contextual information in the form of texts and images. Although this time-frame is relatively brief in comparison with many studies of women's roles in ancient Greece, it approximates to perhaps five generations and, as noted below, there is some evidence to suggest that women's relationship with the civic sphere may have undergone significant change during the fifth and fourth centuries BCE. Similarly, for reasons of space and coherence, my discussion is limited to the city of Athens, excluding the port of Piraeus and the smaller deme centres (village communities) in its territory, Attica: the deme centres were much smaller in scale and probably functioned very differently in social terms. In addition, securely dated evidence for the components and layout of the communal spaces in any of these settlements during the late Archaic and early Classical periods is limited. ${ }^{12}$

\section{Four Athenian case-studies}

Although it is overlain by Greece's modern capital, a remarkable amount is known about the layout of the ancient city of Athens. Unlike many later, planned, Greek cities, Classical Athens was not laid out on a rectilinear grid: instead, the street system seems to have grown up gradually through time. The widest thoroughfare, the Sacred Way, snaked between a major city gate in the Kerameikos district, the Agora (the main civic square) and the Akropolis (the most important religious sanctuary) (Figure 1). While the Agora occupies a relatively flat area north-west of the Akropolis, much of the terrain covered by the ancient city is hilly. In the most intensively investigated neighbourhoods to the west and south-west of the Akropolis, a network of roads of different widths can be traced (Figure 2). The topography sometimes forced major thoroughfares up to six metres in width to follow winding courses along valley bottoms or to ascend slowly up the contours so as to be usable by cart traffic. Nevertheless, in many areas the narrower routes cut across the contours and some sections were passable only on foot, ascending steeply via flights of steps. The adjacent houses were terraced into the hillsides on a variety of orientations, depending on the directions taken by the roads and hill slopes. ${ }^{13}$

\section{Women in urban neighbourhoods}

Where are we to search for the female inhabitants of this densely textured 'urban' environment? The literary-based, polarised model outlined above, which draws a contrast between the domestic and civic spheres, implies a sharp break between the two 


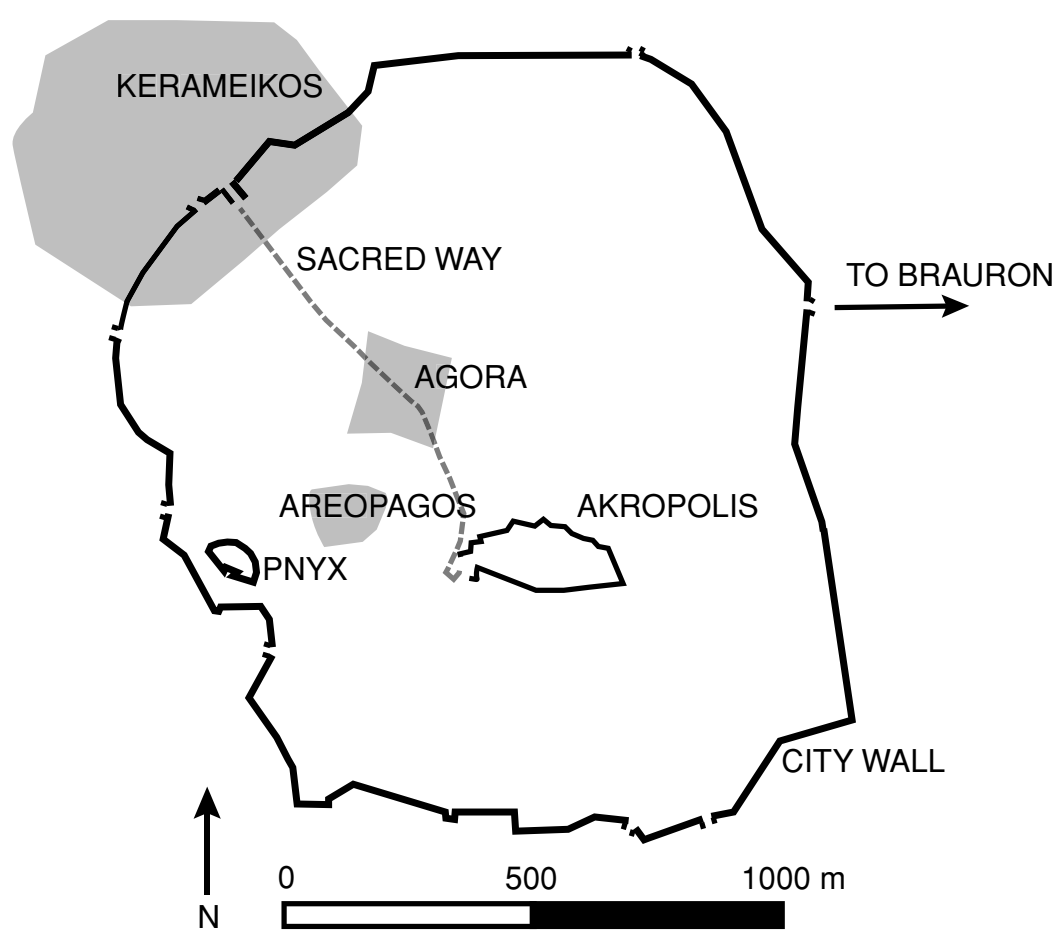

Figure 1: Sketch-map of Athens showing the relative locations of the main civic spaces discussed in the text (the city walls shown are those of early to mid-fifth century BCE).

types of space. This works well where houses were located on major thoroughfares and adjacent to densely trafficked areas, as is the case with the best known and most extensively published, excavated examples in the area around the Agora. ${ }^{14}$ But when taken as a whole, the fabric of the cityscape also suggests the possibility of something more complex, of a range which, in some cases, could also comprise intermediate areas in the immediate neighbourhoods surrounding houses that were located away from the main roads, on the narrower streets and pathways.

The architecture of individual Athenian houses suggests that a heavy emphasis was placed on isolating the interior world of the household from that of the city beyond (Figure 3). Access to the house was normally via a single street door. Communication between that door and the remainder of the rooms was via an open courtyard, usually at the centre or south, which also served as the route for moving between the rooms themselves. Anyone wishing to enter or leave the house, or walk from room to room, would have had to do so knowing that they could be overlooked by anyone else in the house at the time, since the windows providing light for the interior are likely to have opened inwards onto this space rather than outwards into the street. ${ }^{15}$ In some cases additional living accommodation was provided in an upper storey (which may only have covered part of the area of the lower storey). It is unknown whether these upper rooms had windows oriented towards the street, offering a view of the house entrance. 


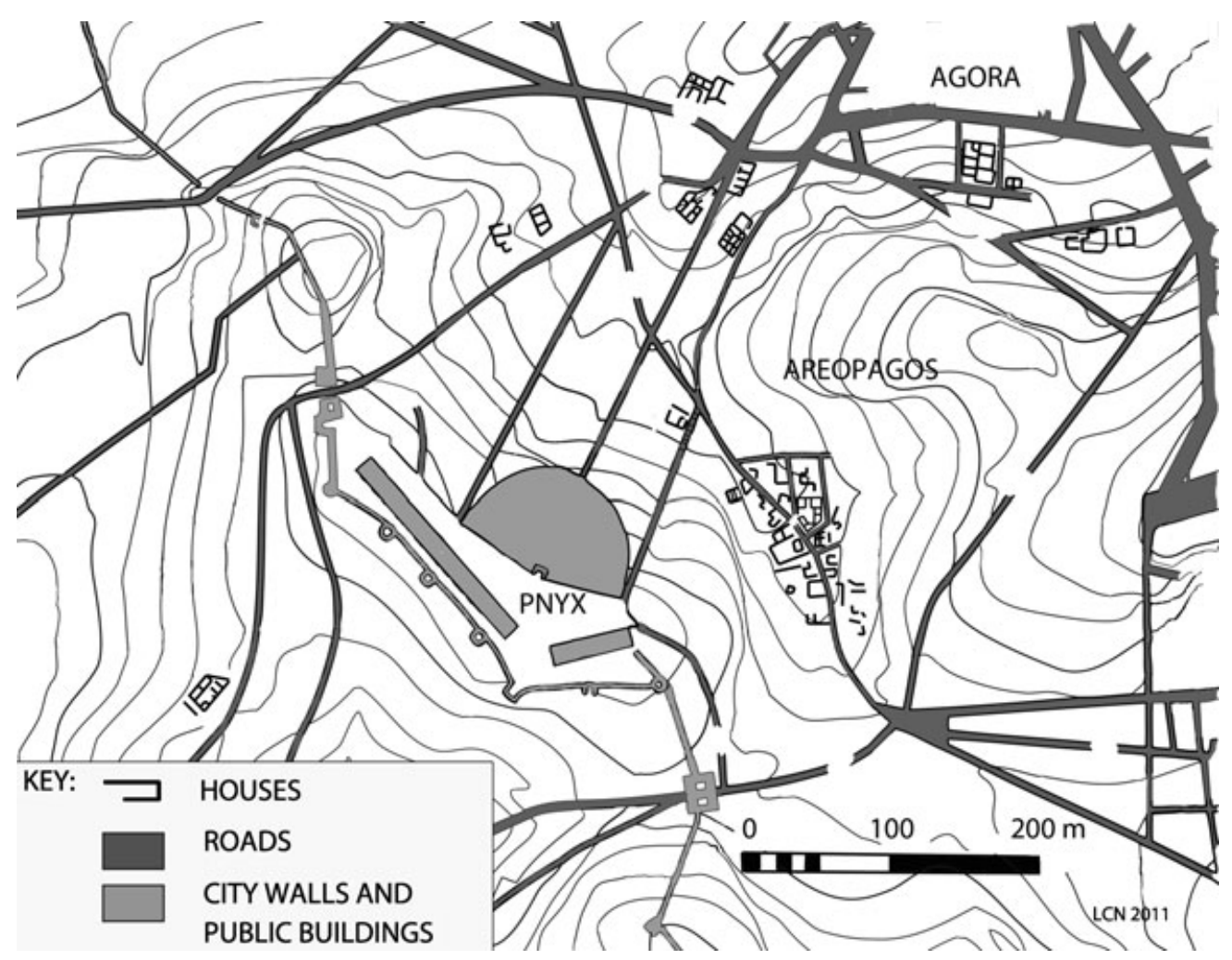

Figure 2: Sketch-map of the residential neighbourhood south-west of the Agora, showing the layout of known and presumed roads together with some of the excavated houses, in relation to the topography, city walls and major public buildings. (Author's reconstruction is based on information contained in Ficuciello, Le Strade and Ellis Jones 'Town and Country Houses', see. n 13).

Depending on the local topography, the entrance, and perhaps even parts of some courtyards, may also have been visible to neighbours looking down from their own upper storeys, especially those whose houses were located further uphill. Even if windows were lacking, roofs are likely to have provided vantage points: finds of terracotta tile suggest that some were pitched, but there were probably also flat areas providing space for a variety of activities, as well as enabling their users to view events in the courtyard, street, on neighbouring roofs or perhaps even in the courtyards of neighbours. ${ }^{16}$ Whether or not looking out from a roof or a window was considered to be a suitable pastime for a 'respectable' woman may well have depended heavily on context. As the documentary sources relating to women's use of balconies in early modern Venice show very vividly, women's presence in such spaces can be construed either as modest (since the women are not easily accessible physically) or as flirtatious or worse (since the women were open to the gaze of individuals outside the household, and could potentially have invited that gaze deliberately). ${ }^{17}$

Given these physical characteristics of the built environment, there was presumably little chance of slipping into or out of an Athenian house unobserved either by other members of the household, or perhaps even by neighbours. This suggests that 

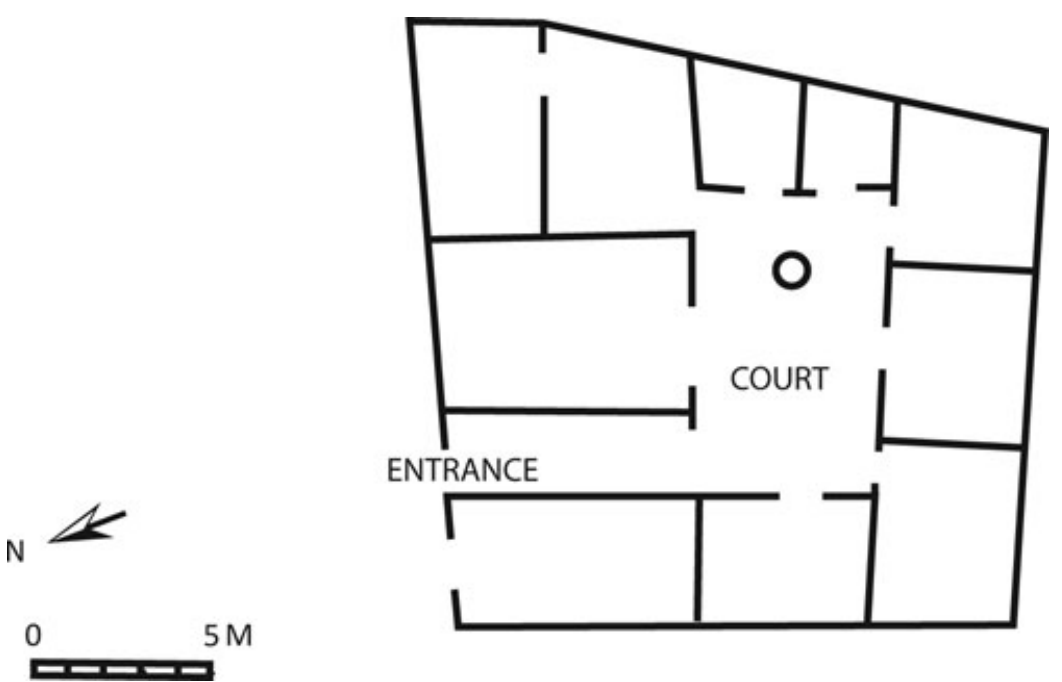

Figure 3: Sketch-plan of an Athenian house: house $\mathrm{C}$ from the Athenian Agora, fifth-century BCE phase (redrawn after Thompson and Wycherley, Agora of Athens, Figure 41).

these individuals are likely to have been complicit in any trips a woman made out of the house, or indeed any visitors she received at home. What, then, is the evidence for women receiving visitors and for their activities outside the home?

Perhaps the most obvious possibility is of women visiting the homes of friends and relatives living close by, which a number of references in literary texts suggest was permissible. ${ }^{18}$ How was it that such forays were able to coexist with the ideal of restrictions on women's movements, articulated by so many of the surviving Classical Athenian texts? In an important article on the spatial and temporal context for women's speech in Greek literature, Josine Blok has argued that the gender associations of some spaces could change through time according to usage. ${ }^{19}$ Here I want to make a related suggestion which also challenges the notion of a fixed division between civic and domestic zones, namely, that there was also a spectrum of associations which could be mapped spatially onto the urban landscape. ${ }^{20}$ The immediate neighbourhood around the house may have lain conceptually between the fully enclosed space of the house and the civic space of the city at large, so that what we may be seeing is a fragmentation of the city into separate neighbourhoods within which female residents may have felt relatively safe and may have been likely to encounter, by and large, relatively fewer strangers.

A similar phenomenon has been seen in cities belonging to other cultures. For example, in the contemporary Islamic world a rhetoric concerning the separation of women and men comparable to that articulated by the Classical Athenian authors has been seen as being tempered by the existence of numerous 'micro-communities'. Spatially these crystallise between the major streets and thoroughfares in large urban landscapes and are focused around their own local facilities such as mosques and fountains. Their role seems to be to mediate between the small scale of the individual house and the larger scales of the neighbourhood and of the city as a whole. ${ }^{21}$ In the 
Classical Athenian context the possibility that there were similar intermediate spatial scales between those of the house and the city as a whole offers a potentially more nuanced understanding of complex patterns of behaviour which may have lain behind some of the rhetoric of female seclusion. Members of the same neighbourhood who knew each other (and may even have had views of each others' houses from vantage points in their own) may not have been regarded as equivalent to individuals from further afield.

Such an interpretation fits with what is preserved of the plan in the residential area discussed above, where the smaller streets are often arranged in parallel sets, forming small neighbourhoods, each one following its own localised orientation (as can be found in the valley between the Areopagos and the Pnyx: Figure 2). Early excavation of housing in this part of the city also suggested that there were discrete neighbourhoods here with their own characters. ${ }^{22}$ While these indications can only be suggestive, a 'micro-community' model is also in keeping with what we know of the pattern of political organisation of Athens and its territory, Attica, which were subdivided into a number of urban and rural 'demes'. These constituted a set of political units which also had some geographical, social and ritual coherence. (The festival of the Thesmophoria, for example, seems to have been celebrated locally by different demes and not by the inhabitants of the city as a whole.) It also makes sense in relation to the history of Athens, which seems to have coalesced over a period of time from a number of spatially scattered, small, communities. ${ }^{23}$

\section{Women at fountain-houses}

A second location, also potentially close to home, which may have been visited by women relatively regularly, was the fountain-house, depicted in both texts and (more frequently) in iconography. Although such images occur on a range of vessel shapes, a particularly prominent group consists of hydriai or water vessels made in Athens and Attica during a relatively short period between about 530 and 490 вСE. The painted decoration on about ninety examples includes women using water spouts to fill hydriai comparable to those on which the images appear (Figure 4). Numerous variations are found: some of the earlier scenes show them proceeding sociably in pairs; most include images of colonnaded buildings - the fountain-houses themselves; occasionally men are included - in several instances filling larger, heavier vessels. ${ }^{24}$

The question of whether these fountain-house episodes are to be taken at face value, as the kinds of everyday occurrences one might have happened upon in the streets of Athens during the late sixth century, is debatable. While some elements are likely to be fantasy, other details seem to speak to a practice with which the painters were familiar. For example, in some cases the hydriai are shown perched sideways on the head, suggesting a technique which made it easier to balance a tall, empty jar. In addition, a padded headdress or polos is occasionally represented - presumably also an aid to balancing the vessel, whether empty or full. ${ }^{25}$ The implication may be, then, that we are dealing with generic scenes which are likely to relate to patterns of behaviour at Athens at the time they were made, indicating that during this period women did visit public fountains to carry water back to the household - even if the fountains and water vessels were perhaps less elaborate, and the women less idealised, than the painters have represented them. 


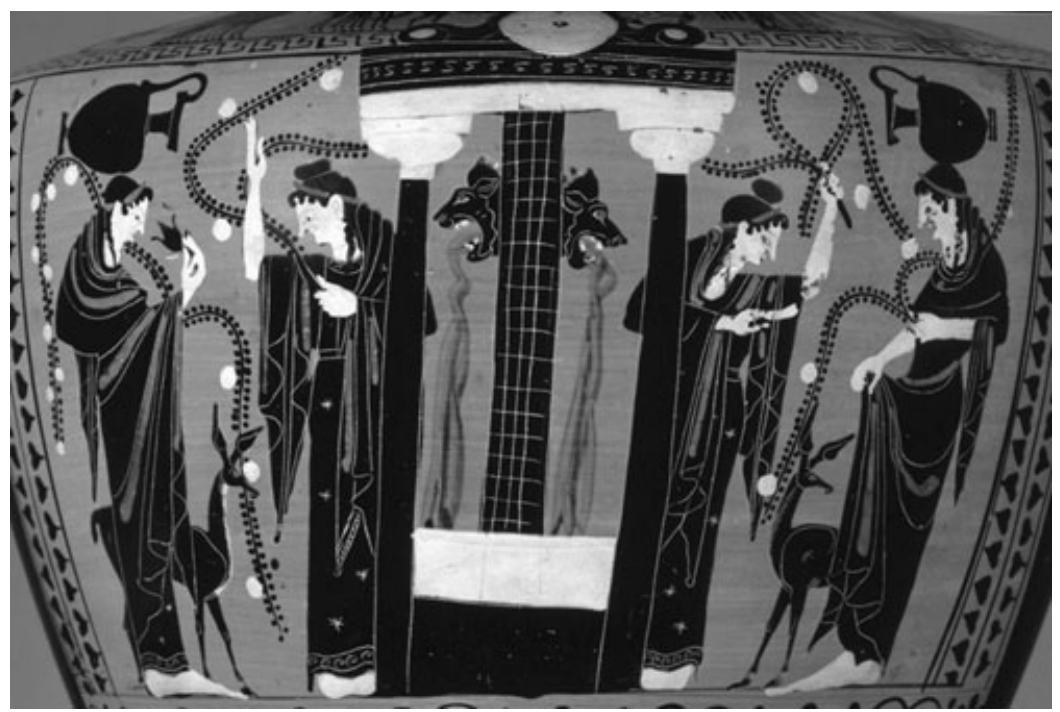

Figure 4: Detail of an Attic black-figure hydria depicting women at a fountainhouse c.520 BCE $\odot$ Trustees of the British Museum.

The period during which these images were produced is equivalent to perhaps a single generation and, as has often been pointed out, coincides with the time of the construction at Athens of the earliest monumental spring- and fountain-houses. These include the famous Enneakrounos or nine-spouted fountain, whose creation the scenes have sometimes been taken to celebrate. ${ }^{26}$ Other examples of new spring- and fountain-houses from this period, attested archaeologically, include one from the south slope of the Akropolis close to a later sanctuary of Asklepios; the so-called Klepsydra on the north slope of the Akropolis; the so-called Southeast Fountain-House on the south side of the Agora; a possible fountain-house on the west side of the Agora under the later Stoa of Attalos; and a fountain-house on the Pnyx, south-west of the Agora (Figure 5). ${ }^{27}$

The number of fountain-houses provided (and more, presumably, have not been discovered) together with the locations of some of them away from the civic centres of the city, suggest that at least some of these sources may have provided water for domestic use. Unfortunately, most were long-lived and the appearance and surroundings of most during the late sixth and early fifth centuries BCE are difficult to reconstruct (apart from the Klepsydra, which, unusually, was built into a cave; and the building beneath the Stoa of Attalos, which, apparently exceptionally, was fully enclosed and could be locked). They do seem to have been important, however, since considerable attention appears to have been paid to their location and construction. The excavated remains of the Southeast Fountain-House in the Agora, for example, show that the foundations, floor surface and terracotta piping were all made very carefully. Its location, close to several other new buildings which may have played a civic role, has been seen as part of a programme to change the function of the area in which it was set, from a private, residential and funerary space into a civic one. The fact that a fountain-house was among the earliest facilities in this newly established arena has been argued to 


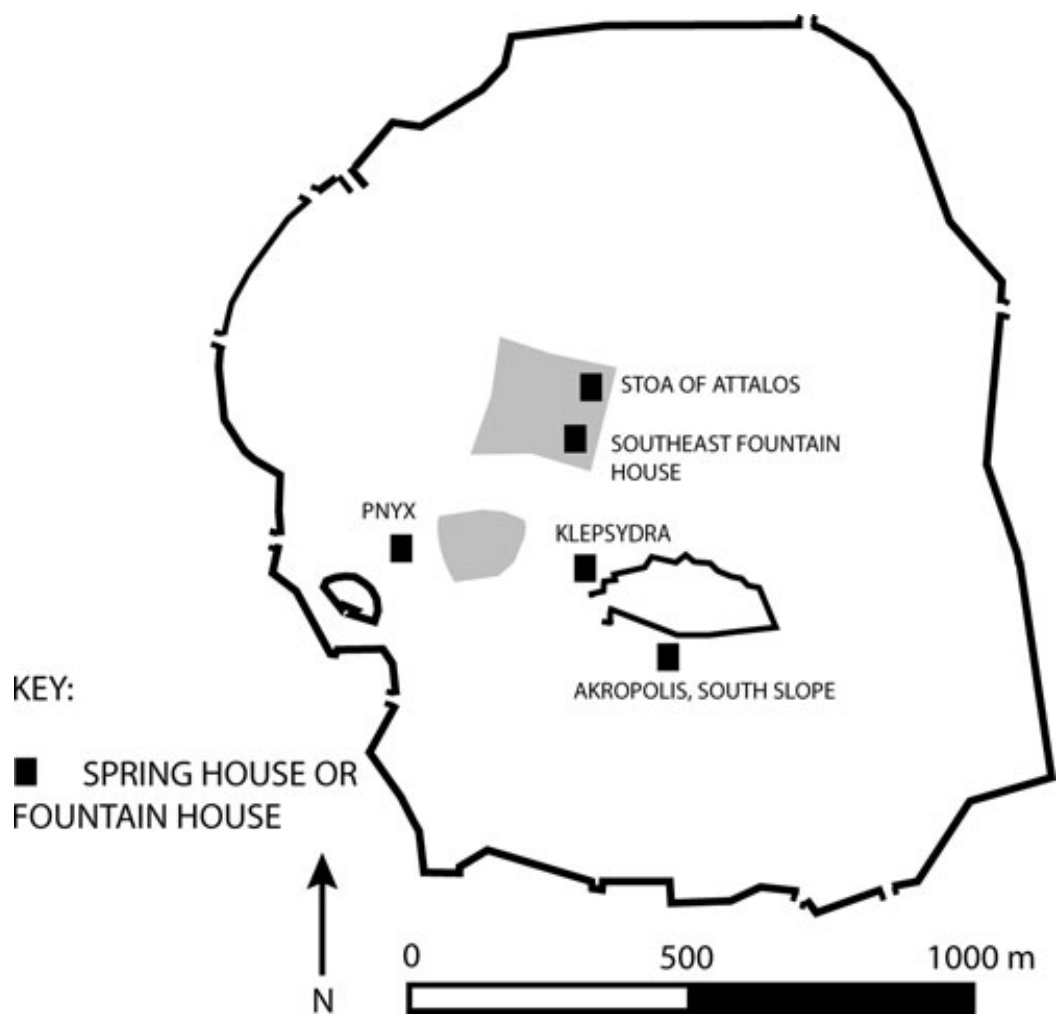

Figure 5: Sketch-map showing the distribution of spring- and fountain-houses of the later sixth and fifth centuries in relation to the topography of Classical Athens.

represent the deliberate inclusion of women in what might otherwise have been a masculine sphere. ${ }^{28}$

If we accept that some, at least, of the users of these fountain-houses were female, then the construction of these facilities during the late sixth and earlier fifth centuries BCE may have had an impact on women's lives, providing alternative or additional sources to the many wells and cisterns that characterise the early residential areas, and potentially turning water collection into a social occasion. At the same time, however, water from a spring- or fountain-house may have had to be carried for longer distances. While the images on painted pottery may have celebrated the provision of these new, and perhaps sometimes elegant, public facilities, any improvement in water quality they may have brought is likely to have had an adverse effect on women's health: the weight of one hydria from the Agora, when filled with water, has been estimated at around sixteen kilograms. ${ }^{29}$

Collecting water may not, therefore, have been the pleasant, easy occasion it sometimes appears on the painted scenes, and this has implications for the status of the women involved. They have been identified variously as dancing girls or as the wives or daughters of citizens. ${ }^{30}$ In a joking description of a fountain-house, the comic playwright Aristophanes says that some of their users were slaves. ${ }^{31}$ Although he 
may be exaggerating for comic effect, it seems plausible that the wives and daughters of wealthier citizens might have avoided such heavy work if they could. Such a presumption is supported by Herodotos who says that collecting water was a job once done by the sons and daughters of the Athenians before domestic slaves were available. ${ }^{32}$ It therefore seems possible that women of a range of statuses gathered at fountain-houses, with those from wealthier families sending or accompanying slaves, while those who could not afford to, carried the water themselves.

It is difficult to know to what extent and in what ways use of spring or fountain water may have been combined with use of water from wells and cisterns. Visits to the fountain-house may have been seasonal, depending on the levels and quality of the water available in the wells and cisterns. It is also possible that the painted scenes represent collection of water for ceremonial or religious purposes rather than for everyday activities. Literary references suggest that women visited the Kallirhoe, in particular, as part of bridal ceremonies, and details of the iconography have been used to suggest that the images of fountain-house scenes themselves represented festivals. ${ }^{33}$ A minority of vessels show mythical or cultic scenes together with the spring-houses, suggesting the possibility of a thematic connection. There are also numerous other iconographic and epigraphic sources which confirm the importance of women for bearing water on religious occasions. It is therefore perhaps difficult, or impossible, to separate women's role as collectors of water for domestic purposes from their role as collectors of water for ritual and cult, and I return to this mingling of domestic and ceremonial activities below.

\section{Women at cemeteries}

While the evidence for fountain-houses offers one of the most visually striking images of women appearing outside the confines of their homes, there are also other, potentially more distant, locations which can be suggested as frequented by women. One of these is the cemetery. The cemeteries of ancient Athens lay outside the walls of the city, the graves lining the roads leading out into the countryside. Visiting a grave site therefore entailed leaving not only the house, but also the built-up area itself. Both iconographic and textual sources indicate that women played a major role in burial rites, including walking in the funerary procession and appearing as mourners. ${ }^{34}$ Indeed, a funeral is cited at least once as the context in which the wife of a respectable citizen struck up an affair with a man other than her husband. ${ }^{35}$ In addition to the funeral itself, visits to the grave by family - especially by male heirs - are reported, particularly on anniversaries and festival days during the year. ${ }^{36}$

Circumstantial evidence from fifth-century literature suggests that women were also envisaged as returning more informally to grave sites to tend the graves. ${ }^{37}$ Women's visits to tombs are also a theme represented on painted pottery: images from a particular class of pottery vessel, the white ground lekythos (a perfume container used for funerals during the fifth century $\mathrm{BCE}$ and deposited in tombs), frequently depict a grave together with a visitor or visitors leaving wreaths, ribbons or other offerings (Figure 6). Often the figures represent one or more women who are shown with or without male companions. These groups are generally interpreted as depicting women from citizen families, perhaps sometimes accompanied by their slaves. ${ }^{38}$ Such scenes may to some extent have been the product of artistic conventions since the inclusion in some of them of 


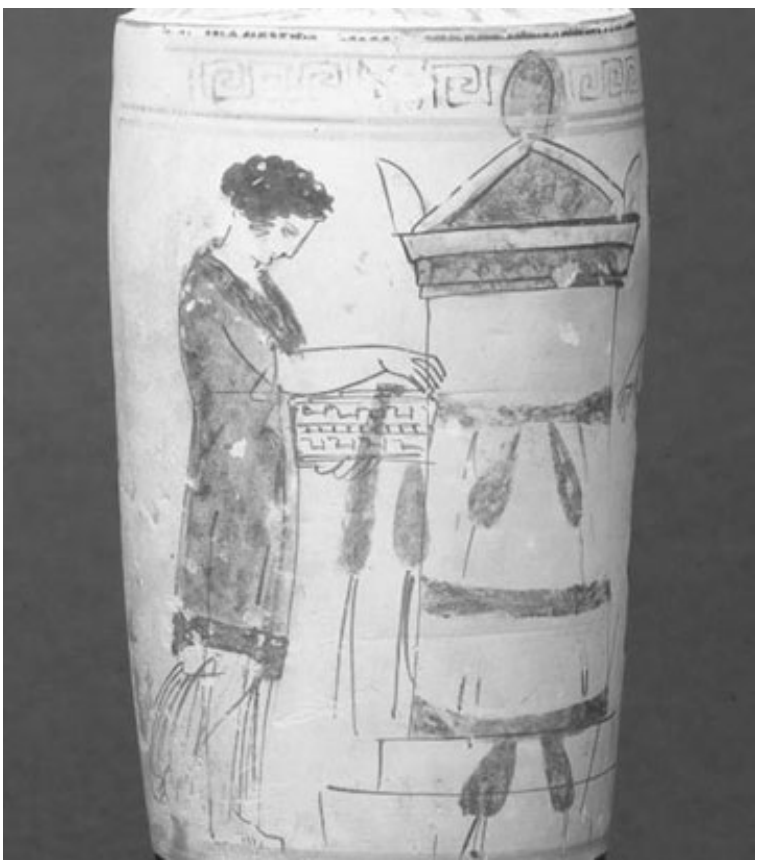

Figure 6: White ground lekythos depicting a woman visiting a grave. Attributed to the Reed Painter, $c .420$ 410 BCE. $\odot$ Trustees of the British Museum.

household objects confirms that they are not realistic in the sense of being snapshots of actual visits to cemeteries. ${ }^{39}$ At the same time, however, such objects tend to appear in iconography more generally in connection with women, suggesting they may have been intended to symbolise that tending to graves was an extension of women's domestic duties.

Sanne Houby-Nielsen has argued that the physical arrangement of some of the graves themselves may also be significant, supporting this idea that women were involved in continuing care for the deceased, particularly infants and children. ${ }^{40}$ She notes that many of the fifth-century burials in Athenian cemeteries are organised in family plots but that the graves of young children are an exception: these frequently cluster just outside specific city gates, close to major roads leading to the extra-mural sanctuaries which hosted cults and festivals of particular importance to women, such as the sanctuary of Artemis at Brauron and the sanctuary of Demeter at Eleusis. The fact that such locations were favoured may suggest that the graves of infants and children were located in areas which were familiar to women and which would facilitate women's visits to them.

Together, the topographic and iconographic evidence suggests that, on occasion, women made their way beyond the confines of their local neighbourhoods, to the boundaries of the city in order to take part in the duty of caring for deceased family members. To some extent this may be perceived as an extension of women's domestic role, as implied by some of the iconography; at the same time women may also have been acting in the capacity of representatives of their households, continuing and 
renewing links with those deceased members - especially, perhaps, infants and young children. My final example, that of women's participation in religious processions, takes this idea a step further, extending not only the geographical reach of women's activities but also the extent to which women seem to have acted as representatives of a larger group - in this case, the polis itself.

\section{Women's participation in religious processions: the examples of the procession of the Great Panathenaia and the procession to Brauron}

The number and diversity of the different religious cults and the complexity of women's engagement in Greek cult practice are particularly large topics. Here I can only be extremely selective, simply highlighting two of a number of processions which would periodically have made women conspicuous in the urban landscape, namely those associated with the Great Panathenaia and with the festival of Brauronian Artemis.

The Great Panathenaia, the major festival to Athens' patron goddess Athena, was initiated in 566 вСE and held every four years. The celebrations included a procession which passed along the Sacred Way from close to the Sacred Gate in the Kerameikos area, through the Agora and up to the sanctuary of Athena on the Akropolis. It is clear that women took part in these processions alongside men: their role is celebrated in the iconography of the Parthenon, where the Ionic frieze seems to represent this procession (or perhaps a more generic combination of different religious processions) and the figures include women, some seemingly just walking, others undertaking a variety of tasks including carrying baskets and vessels. ${ }^{41}$ Aristophanes implies that such tasks were often undertaken by women from elite families and that it was considered an honour to perform them ${ }^{42}$ Inscriptions also record the identities of some of the women who were given such tasks during the fourth century BCE, and these include resident foreigners (metics). The Panathenaic procession has frequently been interpreted as a spatial model of the whole Athenian community, comprising representatives from a range of different social groups. Through its regular performance, the procession acted both to define and to reinforce a clear model of the city's social structure, setting out its range of members and their roles and relationships. ${ }^{43}$ The involvement of women must have been a key element, affirming their role and importance within the polis as a whole, particularly because they were producers and guardians of the next generation. ${ }^{44}$

The procession associated with the festival of Brauronian Artemis (the Brauronia, which also took place every four years) is an example of a number of processions, linked with the worship of a variety of deities, which reversed the direction of the Panathenaic procession. The procession to Brauron is particularly relevant to the present discussion because many of the participants must have been young girls, in keeping with the major concern of the cult which was to facilitate women's passage through puberty. Its details have not been preserved, but it perhaps began at the stoa dedicated to Artemis Brauronia which was located on the Athenian Akropolis and which probably dates back to the later fifth century BCE. If so, participants must have paraded downwards through the city's streets before exiting the walls on its east side. Their ultimate destination was the sanctuary of Artemis at Brauron in eastern Attica, nearly forty kilometres away. ${ }^{45}$

Participants in the cult are likely to have been from relatively well-off families. At the sanctuary itself, inscriptions dating to the late fifth and fourth centuries BCE (versions of which were also found on the Akropolis itself) list numerous items, 
particularly clothing, which were dedicated to the goddess by women, probably as offerings for safety in childbirth. A few of these record patronymics, a high proportion associating the women with families known, through other sources, to have been of high status. At the same time, the journey to Brauron would have entailed spending several days away from home, and the young initiates into the cult also spent a period of time living at the sanctuary and serving the goddess. The absence from home of these women and girls may have been a luxury which a household could not have afforded unless alternative labour sources were available. ${ }^{46}$

It has often been said that ritual processions like that to Brauron were important in the context of the Athenian state as a whole, binding together the city and its large rural hinterland. ${ }^{47}$ But they must also have been significant in periodically emphasising the presence of, and roles played by, the particular social groups taking part - in this case, women, as they made their way through the Attic countryside and out to the sanctuary. The activities of those women seem to have been significant for the well-being of the community as a whole. While the landscape beyond the city walls was punctuated with farms and villages, it was also vulnerable to incursions by enemy forces. The women's passage, unprotected, to an outlying sanctuary such as this one therefore constituted an act of entrusting some of the most vulnerable (and, as the mothers, current or future, of wealthy Athenian families, some of the most valuable) members of society to the protection of the goddess. (The dangers involved are emphasised by the Greek historian, Herodotos, in a story about the early history of the cult at Brauron, when a group of women worshipping there were said to have been kidnapped and carried off to the island of Lemnos.) The women's safe arrival at the sanctuary would thus have been symbolic of the goddess's protection of Athens as a whole. ${ }^{48}$

\section{Discussion}

Each of these four case-studies is brief and selective, but together they demonstrate that women were present in the urban landscape in a range of contexts. Not only did women move through the streets within their own neighbourhoods en route (for example) to the houses of friends and relatives, or to collect water at a fountain- or spring-house, but they also covered greater distances through the city, to its very boundaries - the locations of burials - and beyond into the countryside to outlying sanctuaries. An important and recurring question touched on in each of these cases has been the social identities of these women. Scholars have long pointed out that ideals of female seclusion are likely to have been implemented to varying degrees by women belonging to different status groups: any restrictions on women's movements can be applied more readily in the context of elite families with the economic resources to employ slaves or servants for chores requiring activity outside the house, such as collecting water from a fountain-house. ${ }^{49}$ As we have already seen, however, our examples cannot all be assigned easily to such low-status groups: visits to friends and family, tending burials and participation in religious activities are all duties that seem to have formed an important part of the role of a citizen woman.

In addition to socio-economic status, it is also relevant to think about the age of the women involved: ideals of seclusion may have been invoked particularly for women during certain stages of their lives. Analogy with some modern Islamic societies in which such ideas are prevalent suggests the possibility that expectations about the 
behaviour of married women may not have been the same as those for pre-pubescent girls and elderly women, with girls and older women frequently being able to move more freely through civic space. ${ }^{50}$ Thus it is possible that at least some obligations requiring the use of more public spaces (such as collecting water from a fountainhouse) or travel further from home (such as tending a grave or taking part in a religious procession) may have been undertaken more frequently by members of these groups. At the same time, however, there were clearly other ways in which a degree of modesty could co-exist with a certain amount of freedom to move through the more 'public' spaces of the city. Here it is relevant to think about how the activities of the city's female occupants intersected with those of its male residents: at particular times of day the majority of citizen men may have been absent from their own neighbourhoods, taking part in agricultural or commercial activity or participating in the business of the polis. On a longer time-scale, there are likely to have been seasons of the year when many men travelled further afield and were absent for periods of time, such as when intensive labour was required in the countryside, or when a city was at war. The presence of women in the urban landscape may have been a particularly frequent phenomenon at such times. The gender associations of certain spaces within the city may therefore have changed on a cyclical basis over a relatively short time-frame.

Even when men were present in significant numbers, there may have been additional strategies women could use to move through civic space while remaining relatively inconspicuous: Lloyd Llewellyn-Jones has recently drawn attention to the fact that a number of painted and sculpted images represent women with a variety of different forms of head covering or veil, some of which appear to have been drawn across the face. Although it is unclear how frequently these were used or in what contexts, such devices may have served as a means by which a woman travelling through the city could make herself unidentifiable. To modern, Western scholars this may seem an infringement on female liberties, but as Llewellyn-Jones points out, such a practice may in fact have enabled high-status, married women to occupy the civic space of a Greek city in the presence of men to an extent that would otherwise have been socially unacceptable. ${ }^{51}$ Additionally, elite Greek women are sometimes assumed to have used chaperones (whether male or female), which may have served a similar purpose..$^{52}$

\section{Interpretation}

By sampling a few of the different contexts in which women may have moved through the civic spaces of ancient Athens, it becomes clear that women were present both in residential neighbourhoods and on major roads leading out of town. The journeys documented here seem to have represented extensions of women's domestic duties, either at a formal level or at an informal one. These activities varied in periodicity, taking in both potentially frequent visits to friends and relatives or to neighbourhood facilities such as fountain-houses, and also journeys undertaken at longer intervals, such as religious processions and funerals. Women's movements therefore formed a series of interlocking cycles and an individual woman's path through these cycles and her use of civic space were shaped by a number of factors, including her age and the social status and wealth of her family. At least some of the spaces through which women moved are likely to have been relatively flexible in their patterns of gender 
associations, and to have been classified and re-classified depending on a variety of factors, including time of day, the season of the year and, most directly, the identities of those present at any one time.

The examples discussed here should be viewed as illustrations that represent a small part of the total web of women's lives and movements; they are intended only to serve as an indication of the range and extent of women's familiarity with, and activities in, the urban - and also the extra-urban - landscape. Numerous other duties will also have taken women out of their houses in similar ways - including the religious and economic activities mentioned in my Introduction. While this pattern of spatial behaviour contradicts the dominant rhetoric of the ancient authors, which articulates an ideal of exclusion of women from the civic sphere, it is also, as we have seen, detectable through many passing references made in the Attic texts. Together with the iconographic and archaeological evidence, these make clear that women's presence could constitute, on occasion, a form of active participation in the life of the polis.

Athenian civic space was thus an inverse parallel for the city's domestic space, which was ideologically constructed as a female domain even though it was, in fact, an important location for male activity. Therefore, although the boundaries and gender associations of the different spheres are represented in the textual sources as rigid, in the reality of day-to-day practice they are likely to have been blurred by the behaviour of individuals. The right to leave their homes for specific purposes and to move around the city's civic spaces gave women a potential basis for challenging the cultural ideology, ${ }^{53}$ and in fact criticism of women for leaving their homes too much is something of a literary topos, while women at windows and doors are also a subject of interest for vase-painters. ${ }^{54}$ At the same time, however, such challenges may have been limited by the goals of the women themselves: in contemporary societies subscribing to ideals of female seclusion, some women have reportedly commented positively that seclusion brings freedom from the need to work outside the home and is a symbol of status and wealth. ${ }^{55}$ In the ancient Greek context, too, it is possible that some women, at least, may have had an ambivalent attitude, seeing an advantage in colluding with men to maintain an ideology of female seclusion, while at the same time stretching the boundaries of that ideology in their daily lives. There was thus considerable scope for individual agency in determining a course between these alternatives. Similarly, the organisation of space within the house itself, with its potential for monitoring movement, suggests that members of the household, including men when they were at home, and even perhaps neighbours, may have been aware of anyone entering, leaving or moving around the house.

Thus it seems possible that there was a level of collusion on the part of both men and women to ensure, first, that an appearance of modesty was upheld, but that, second, women were in reality able to leave the house more freely than the ideal may have suggested, in order to carry out the full range of duties necessary for the maintenance of the household and its relationship with the wider community. A similar form of collusion, which preserved male prestige in the public sphere while allowing women power at home, was observed by anthropologists working in the Mediterranean during the mid-twentieth century; at the same time, a disjunction between verbal articulation and actual social behaviour has been noted in cross-cultural research on the use of space. ${ }^{56}$ 


\section{Implications: Late Archaic and Early Classical Athens in a broader geographical and chronological context}

The wider implications of this argument for other periods and communities are difficult to assess. Studies of Greek social relationships have frequently drawn on material from several centuries or more, which have been conflated to produce a composite, static picture. There is, however, some evidence that social expectations - and patterns of behaviour - changed significantly through time. I have argued elsewhere that major alterations in the organisation of domestic space during the sixth and fifth centuries suggest a corresponding change in the behaviour of individual household members and an increasing sensitivity to issues of gender. ${ }^{57}$ Shifts in the relationship between the two sexes have also emerged from studies of other forms of evidence. For example, Matthew Dillon has highlighted the way in which inscriptions on dedications from women which were left on the Athenian Akropolis changed radically from the period before $480 \mathrm{BCE}$, when women made offerings in their own right, through the period from 480 to $450 \mathrm{BCE}$, when they were always identified by a patronymic, to the period after $c .450$ BCE, when only dedications by men are recorded. ${ }^{58}$ Similarly, Llewellyn-Jones has argued that a fuller form of head covering became more common during the fourth century $\mathrm{BCE}$ and interprets this as indicative of new patterns in female behaviour. ${ }^{59}$ Such evidence demonstrates a need for sensitivity to the way in which behavioural ideals and patterns of activity may have altered over a period of a few generations, requiring close scrutiny of the chronological context of our material.

The extent to which conclusions drawn on the basis of the Athenian material can be applied to other Greek cities is also unclear. Archaeological evidence suggests that by the fifth century BCE, houses across the Greek world were shaped by similar cultural expectations about appropriate patterns of behaviour for their inhabitants. ${ }^{60}$ Athens was, nevertheless, exceptional in many ways. The rich textual and iconographic evidence used in this paper is not available for other Greek communities, making it difficult to explore potential congruences and conflicts between dominant ideologies and day-to-day patterns of behaviour in those contexts. At the same time, the sheer scale of the city of Athens, and also, perhaps, its severe limitation of women's legal rights, render the situation there potentially rather different from other communities. At a more basic level, there are also likely to have been contrasts between such a large, irregularly planned city and smaller, grid-planned communities, in the extent to which discrete neighbourhoods formed within the larger urban context.

Closer attention to the architecture of Greek cities, viewing them as lived spaces rather than as composed of isolated monuments, should begin to reveal some of these patterns. It will be particularly important to integrate the study of civic and domestic spaces into a single connected whole: at a theoretical level, study of the relationship between the two in the context of the broader ideological system of the polis can inform our understanding of both spheres. From a more practical perspective, such integration should also enable communication routes and the structuring of neighbourhoods to be studied alongside the distribution and accessibility of different functional areas. Such work can be done retrospectively at a few extensively investigated sites, using published data (an aim of my own ongoing research), but much more could be learned 
through new excavations with these questions in mind, paying close attention to, for example, artefact assemblages and their distributions, which should reveal more about patterns of activities and the identities of those carrying them out.

The material remains of Greek cities therefore represent a potentially rich source of evidence about the gendering of civic space. In this paper, I have only begun to explore in a preliminary way a few of the complex issues and data-sets available for such an investigation, but I hope I have shown that bringing different sources into dialogue offers the prospect of a much richer and more nuanced picture, highlighting some of the ways in which women were able to navigate and negotiate the civic space of Greek cities.

\section{Notes}

I am very grateful to Lin Foxhall for suggesting that I submit a paper for the conference and for consideration for this volume. This paper represents a first attempt to sketch and interpret a few aspects of a vast and complex topic; I plan to explore these and other dimensions of women's use of space in Classical Greek cities in more detail in future publications, but it has proved very useful and stimulating to explore some preliminary ideas in this inter-disciplinary, cross-cultural context. I would like to thank the other participants, and especially Lin Foxhall and two anonymous referees, for their very helpful ideas and suggestions. David Stone also commented on the text and assisted with producing some of the figures. I am extremely grateful to Penelope Wilson Zarganis of the British School at Athens for help with procuring maps, and I thank the Trustees of the British Museum for permission to reproduce Figures 4 and 6 .

1. James Davidson (this volume) discusses this traditional interpretation of the texts in more detail. Studies of ancient Greek women have not rejected the straightforward equation of women with the home on theoretical grounds, as has been done in a range of other disciplines. See e.g., Dorothy O. Helly and Susan Reverby (eds), Gendered Domains: Rethinking Public and Private in Women's History (Cornell, NY: Cornell University Press, 1992); Elizabeth Brumfiel, 'Gender, Households, and Society: An Introduction', Archaeological Papers of the American Anthropological Association 18 (2008), pp. 1-16. Nevertheless, it has been pointed out that not all the data support such a literal interpretation: e.g., Walter Scheidel has stressed the large proportion of women in antiquity whose families relied on agriculture and who are therefore likely to have been called upon to augment the labour force on an occasional or regular basis. Walter Scheidel, 'The Most Silent Women of Greece and Rome: Rural Labour and Women's Life in the Ancient World (i)', Greece and Rome 42 (1995), pp. 202-17; Walter Scheidel, 'The Most Silent Women of Greece and Rome: Rural Labour and Women's Life in the Ancient World (ii)', Greece and Rome 43 (1996), pp. 1-10. Similarly, Roger Brock has explored evidence for a wide range of economic activities undertaken by ancient Greek (mainly Athenian) women, including selling goods at market. Roger Brock, 'The Labour of Women in Classical Athens', Classical Quarterly 44 (1994), pp. 336-46.

2. I use the term 'gender' in this paper to refer to the sex distinction between male and female, which in the ancient Greek context was one of the overriding divisions governing the social and political spheres: compare Barbara Goff, Citizen Bacchae (Berkeley: University of California Press, 2004), p. 20.

3. Pauline Schmitt-Pantel, 'Histoire des femmes en histoire ancienne aujourd'hui', in Pauline Schmitt-Pantel (ed.), Histoire des Femmes en Occident, vol. 1: L'antiquité (Paris: Plon, 1991), pp. 493-502; Lisa Nevett, 'Domestic Facades: A Feature of the Greek “Urban” Landscape?', in Sara Owen and Laura Preston (eds), Inside the City in the Greek World (Oxford: Oxbow, 2009), pp. 118-30. On the domestic symposium in particular, see Lisa Nevett, Domestic Space in Classical Antiquity (Cambridge: Cambridge University Press, 2010), pp. 43-62.

4. This is most obvious in the case of priestesses. See e.g., Joan Connelly, Portrait of a Priestess (Princeton: Princeton University Press, 2007).

5. So, e.g., 'The women of ancient Greece were ... secluded, excluded ... never supposed to take a place in history': Goff, Citizen Bacchae, p. 25; compare Connelly, Portrait of a Priestess, pp. 3-4, summarising some of the different ways in which the evidence has been interpreted.

6. See e.g., David Cohen, 'Seclusion, Separation and the Status of Women in Classical Athens', Greece \& Rome 2nd ser. 36 (1989), pp. 1-15; David Cohen, Law, Sexuality and Society (Cambridge, Cambridge University Press, 1991), p. 151. 
7. See e.g., Elizabeth De Marrais, 'The Materialization of Culture', in Elizabeth De Marrais, Chris Gosden and Colin Renfrew (eds), Re-Thinking Materiality: The Engagement of Mind with the Material World (Cambridge: MacDonald Institute of Archaeology, 1996), pp. 11-22, here p. 12.

8. Wolfram Hoepfner and Ernst-Ludwig Schwandner, Haus und Stadt im klassischen Griechenland (1986; Munich: Deutscher Kunstverlag, 1994).

9. J. F. Bommelaer, 'DAI, Wohnen in Der Klassischen Polis, Bd. 1', review of Hoepfner and Schwandner, Haus und Stadt im klassischen Griechenland, in Revue Archéologique (1988), pp. 395-7.

10. Among many possible examples, see e.g., Amos Rapoport, The Meaning of the Built Environment (Beverly Hills, CA and London: Sage, 1982); Bill Hillier, Space Is the Machine: A Configurational Theory of Architecture (Cambridge: Cambridge University Press, 1996); Sophia Psarra, Architecture and Narrative: The Formation of Space and Cultural Meaning (London and New York: Routledge, 2009); Nicole Boivin, Material Cultures, Material Minds: The Impact of Things on Human Thought, Society and Evolution (Cambridge: Cambridge University Press, 2008).

11. See e.g., Aubrey Cannon, 'The Quantification of Artefactual Assemblages: Some Implications for Behavioural Inferences', American Antiquity 48 (1983), pp. 785-92; Roberta Gilchrist, 'Archaeological Biographies: Realizing Human Lifecycles, -Courses and -Histories', World Archaeology 31 (2000), pp. $325-8$.

12. The most extensive evidence for a deme site of this period is Thorikos, although it may not be typical. See Herman Mussche, Thorikos: A Mining Town in Ancient Attika (Ghent: Belgian Archaeological School in Greece, 1996) for an accessible introduction with further references.

13. For the urban plan of ancient Athens, see Walther Judeich, Topographie von Athen (1905; Munich: Beck, 1931); and, most recently, Laura Ficuciello, Le Strade di Atene (Salerno: Pandemos, 2008). Housing districts are discussed in Emile Burnouf, 'Notice sur le plan d'Athènes', Archives des Missions Scientifiques et Littéraires 5 (1856), pp. 64-88, esp. pp. 73-5; Emile Burnouf, Mémoires sur l'antiquité (Paris: Maisonneuve, 1879), pp. 315-19; John Ellis Jones, 'Town and Country Houses of Attica in Classical Times', in Herman Mussche (ed.), Thorikos and Laurion in Archaic and Classical Times (Ghent: Miscellanea Graeca, 1975), pp. 63-140. Athenian residential districts will be treated in more detail in Lisa Nevett, Ancient Greek Housing (Cambridge: Cambridge University Press, forthcoming).

14. Summarised in Homer Thompson and R. E. Wycherley, Athenian Agora, vol. 14: The Agora of Athens: The History, Shape and Uses of an Ancient City Center (Princeton: American School of Classical Studies at Athens, 1972), pp. 173-83.

15. The Aristotelian Constitution of the Athenians [Ath. Pol.] 50.2 makes explicit reference to officials whose duties included preventing the construction of buildings with balconies overhanging the streets or windows looking out onto them. Excavated material includes evidence (in the form of post-pits) for one property which did have an upper level overhanging the street. While this could have been a balcony, as the excavators suggest (Thompson and Wycherley, Agora of Athens, p. 177), the overhang could also have been completely enclosed forming part of an upper storey room or may have been a landing giving separate access to an upper storey flat, as reconstructed by Ellis Jones, 'Town and Country Houses', Figure 22.3). To my knowledge, no published Classical Athenian house preserves evidence for the form or location of windows. While windows are shown on some vase-paintings, their location (whether overlooking courtyard or street) is unclear, and some images, at least, represent scenes from myth or drama, so that they cannot be used as evidence for the actual form of house exteriors. For discussion, see Christoph Löhr, 'Griechische Häuser: Hof, Fenster, Türen nach 348 v. Chr', in Wolfram Hoepfner and Wolf-Dieter Heilmeyer (eds), Licht und Architektur (Tübingen: Ernst Wasmuth, 1990), pp. 10-19; Eva Parisinou, 'Lighting Dark Rooms: Some Thoughts about the Use of Space in Early Greek Domestic Architecture', in Ruth Westgate, Nick Fisher and James Whitley (eds), Building Communities: House, Settlement and Society in the Aegean and Beyond (London: British School at Athens, 2007), pp. 213-23. In a handful of preserved, stone-built houses of third- and second-century BCE date surviving elsewhere in the Greek world, such lower-storey windows as were constructed were placed well above head height - at least $2.5 \mathrm{~m}$ above ground level. See N. G. L. Hammond, 'Hellenic Houses at Ammotopos in Epirus', Annual of the British School at Athens 48 (1953), pp. 135-40, esp. pp. 136, 139.

16. On roofing, see Thompson and Wycherley, Agora of Athens, p. 179. Texts mention a variety of uses for the roof, including as a place from which to observe activity in the street (Lysias 3.11) or to view religious processions (e.g., Aristophanes Acharnians 262). An early fifth-century BCE stele from Thasos (northern Greece) includes a provision forbidding women from appearing on roofs or at windows, although the nature of the buildings concerned ('dèmosia katoikia') is unclear. See Hervé Duchêne, La Stèle du port. Fouilles du port 1: Recherches sur une nouvelle inscription Thasienne, Etudes thasiennes 14 (1992), p. 20, see pp. 50-52 for the clause describing the buildings; John W. Graham, 'The Woman at the Window: 
Observations on the 'Harbour Stele' from Thasos', Journal of Hellenic Studies 118 (1998), pp. 22-40, the latter with a detailed account for textual references to, and images of, roof space and windows.

17. See Alexander Cowan, this volume.

18. For example: neighbourhood women sharing meals at each others' houses (Aristophanes Assembly Women 348-9); making night-time visits, either to light a lamp (Lysias 1.14) or to spend the night (Aristophanes Women at the Thesmophoria 795-6).

19. Josine Blok, 'Virtual Voices: Towards a Choreography of Women's Speech in Classical Athens', in André Lardinois and Laura McClure (eds), Making Silence Speak: Women's Voices in Greek Literature and Society (Princeton: Princeton University Press, 2001), pp. 95-116.

20. David Cohen, Law, Sexuality and Society (Cambridge: Cambridge University Press, 1991), p. 74 comments, based on the literary texts, that the private sphere could encompass more than just the house, and that the distinction between 'public' and 'private' spheres was not a straightforward, binary one, but rather that the two were in relational opposition to each other with the potential to be formulated and re-formulated depending on context. Josine Blok makes a similar point, also emphasising the importance of time in gendering space: 'Virtual Voices', p. 98, an aspect to which I return below.

21. See Stefano Bianca, Urban Form in the Arab World: Past and Present (London: Thames and Hudson, 2000), pp. 150-54 for both the term 'micro-community' and the description of this phenomenon.

22. Robin Osborne, 'The Streets of Athens', review of Ficuciello, Le Strade di Atene, in Classical Review 59 (2009), pp. 591-2.

23. See Kevin Clinton, 'The Thesmophorion in Central Athens and the Celebration of the Thesmophoria in Attica', in Robin Hägg (ed.), The Role of Religion in the Early Greek Polis (Stockholm: Paul Åstroms Forlag, 1996), pp. 111-25 for local celebration of the Thesmophoria. On the settlement pattern of seventhcentury Attica see e.g., Anna-Maria D'Onofrio, 'The 7th Century BC in Attica: The Basis of Political Organization', in Helle Damgaard Andersen, (ed.), Urbanization in the Mediterranean in the 9th to 6th Centuries BC (Copenhagen: Museum Tusculanum Press, 1997), pp. 63-88.

24. Susanne Pfisterer-Haas, 'Mädchen und Frauen am Wasser: Brunnenhaus und Louterion als Orte der Frauengemeinschaft und der möglichen Begegnung mit einem Mann', Jahrbuch des Deutschen Archäologischen Instituts 117 (2002), pp. 1-80, gives an extensive catalogue of spring-house scenes, from a variety of vessel forms.

25. Annie Dufaut, 'How Carrying Water Affects Women's Health', in Charles Kerr (ed.), Community Health and Sanitation (London: Intermediate Technology Publications, 1990), pp. 30-36, esp. p. 31 lists a variety of devices for carrying water in twentieth-century societies.

26. See e.g., William B. Dinsmoor, The Architecture of Ancient Greece (New York: Biblo and Tannen, 1973), p. 118. Compare the image from a fragmentary vessel found on the Akropolis on which the fountain-house is labelled 'KALIROE' - cited by some of the ancient authors as the name of the spring prior to construction of the Enneakrounos. See Nikolaos Kaltsas and Alan Shapiro (eds), Worshipping Athena: Ritual and Reality in Classical Athens (New York: Alexander Onassis Fund USA, 2008), catalogue no. 138. For literary references to the Kallirhoe, see R. E. Wycherley, Athenian Agora, vol. 3: Literary and Epigraphical Testamonia (Princeton: American School of Classical Studies at Athens,), pp. 137-42.

27. Franz Glaser, Antike Brunnenbauten (KPHNAI) in Griechenland (Akademie der Wissenschaften: Vienna), p. 167 with further references. As has frequently been noted, Pausanias' late identification of the Southeast Fountain House in the Agora as the Enneakrounos conflicts with a number of earlier sources situating the Enneakrounos further to the east, close to the Illisos River: the difficulties are summarised, and an ingenious solution proposed, in E. J. Owens, 'The Enneakrounos Fountain House', Journal of Hellenic Studies 102 (1982), pp. 222-5.

28. See Thompson and Whycherley, Agora of Athens, pp. 197-9; John Camp, The Archaeology of Athens (New Haven: Yale University Press, 2001), p. 35 for the construction and location of the Southeast FountainHouse. On the gender associations, see Lin Foxhall, 'Gender', in Kurt Raaflaub (ed.), Companion to Archaic Greece (Oxford: Blackwell, 2009), pp. 483-507, esp. p. 505.

29. Susan Rotroff and Robert Lamberton, Women in the Athenian Agora (Princeton: American School of Classical Studies at Athens, 2006), p. 7. It is unclear how representative this is or how often such vessels would have been carried. Dufaut, 'Carrying Water', p. 32-4 puts the average weight of water carried on women's heads in developing countries today at $25-40 \mathrm{~kg}$, outlining detrimental effects on women's health which may leave lasting traces on their skeletons. To my knowledge no study of osteological samples from Athenian cemeteries has yet identified this kind of damage, but such effects may come to light in future, perhaps helping to clarify the age and status of some of the women involved. 
30. For examples, see the negative view of Gloria Ferrari, 'Myth and Genre on Athenian Vases', Classical Antiquity 22 (2003), pp. 37-54, esp. pp. 44-50, vigorously challenged by Cynthia Kosso and Kevin Lawton, 'Women at the Fountain and Well: Imagining Experience', in Cynthia Kosso and Ann Scott (eds), The Nature and Function of Water, Baths, Bathing, and Hygiene from Antiquity through the Renaissance (Leiden: Brill, 2009), pp. 87-108.

31. Aristophanes Lysistrata, 327-30.

32. Herodotos 6.137.

33. See Wycherley, Literary and Epigraphical Testimonia, no. 438, for the association between the Kallirhoe and weddings. See Dyfri Williams, 'Women on Athenian Vases: Problems of Interpretation', in Averil Cameron and Amélie Kuhrt (eds), Images of Women in Antiquity (1983; repr. London: Routledge, 1993), pp. 92-106, esp. pp. 102-5, for the possible link between the fountain-house scenes and festivals. A potential religious connection for these scenes is also considered by Lise Hannestad, 'Slaves and the fountain house theme', in H.A.G. Brijder (ed.) Ancient Greek and Related Pottery (Amsterdam: Allard Pierson, 1984), here p. 255.

34. On the nature and significance of the funeral procession, see Athina Kavoulaki, 'Crossing Communal Space: The Classical Ekphora, "Public" and "Private", in Véronique Dasen (ed.), Idia kai demosia: Les Cadres 'privés' et 'publics' de la religion grecque antique. Actes du IXe colloque du Centre International d'Étude de la religion grecque antique (Cierga), tenu à Fribourg 8 au 10 Septembre 2003 (Strasbourg: Kernos Supplement 15, 2005), pp. 129-45.

35. Lysias 1.8 .

36. For a recent view of women's roles in relation to funerary rites, with references to previous literature, see Kerri J. Hame, 'Female Control of Funeral Rites in Greek Tragedy: Klytaimestra, Medea and Antigone', Classical Philology 103 (2008), pp. 1-15.

37. Literary examples of women's visits to the graveside include Aeschylus' Elektra, who promises to visit her father's tomb to pour an offering on the occasion of her future marriage: Libation Bearers 488; Sophokles' Klytemnestra pledges to make monthly offerings at the tomb of her dead husband Agamemnon: Elektra 277-81.

38. See H. Alan Shapiro, 'The Iconography of Mourning in Athenian Art', American Journal of Archaeology 95 (1991), pp. 629-56, here pp. 649-55, who identifies pairs of women as representing a mistress with her slave, although the grounds for this are not made explicit. The white ground lekythoi receive comprehensive treatment by John Oakley, Picturing Death in Classical Athens (Cambridge: Cambridge University Press, 2004), who suggests that the images are intended to show women from citizen families, pp. 158-65.

39. Oakley, Picturing Death, pp. 145-6.

40. Sanne Houby-Nielsen, 'Women and the Formation of the Athenian City State: The Evidence of Burial Customs', Metis 11 (1996), pp. 233-60.

41. See the papers included in Jennifer Neils (ed.), Goddess and Polis: The Panathenaic Festival in Ancient Athens (Princeton: Princeton University Press, 1992), for detailed discussion of the Panathenaia. The frieze was probably carved between 443 and 438 вCE. For a summary of possible interpretations see Jeffrey M. Hurwit, The Acropolis in the Age of Pericles (Cambridge: Cambridge University Press, 2004), pp. 224-36.

42. Aristophanes Lysistrata, 641-7.

43. See e.g., Fritz Graf, 'Pompai in Greece', in Robin Hägg (ed.), The Role of Religion in the Early Greek Polis (Stockholm: Paul Astroms Forlag, 1996), pp. 55-65, esp. pp. 57-59; Athina Kavoulaki, 'Processional Performance and the Democratic Polis', in Simon Goldhill and Robin Osborne (eds), Performance Culture and Athenian Democracy (Cambridge: Cambridge University Press, 1999), pp. 293-320, esp. pp. 293, 297-8.

44. See e.g., Mary Lefkowitz, 'Women in the Panathenaic and Other Festivals', in Jennifer Neils (ed.), Worshipping Athena: Parthenaia and Parthenon (Madison: University of Wisconsin Press, 1996), pp. 78-91, esp. p. 85.

45. See Robin Osborne, Demos: The Discovery of Classical Attika (Cambridge: Cambridge University Press, 1985), pp. 154-74 for detailed discussion of the cult, its associated buildings and epigraphic evidence, with further references.

46. Liza Cleland, The Brauron Clothing Catalogues: Text, Analysis, Glossary and Translation (Oxford: British Archaeological Reports, 2005) for the clothing catalogues. For the status of the women involved in the procession, see Matthew Dillon, Girls and Women in Classical Greek Religion (London: Routledge, 2002), pp. 201-3. The patronymics from the Akropolis inscriptions are discussed by Osborne, Demos, p. 159. 
47. François de Polignac, Cults, Territory, and the Origins of the Greek City-State (Chicago, IL: University of Chicago Press, 1995), esp. pp. 32-88.

48. Herodotos' account of the kidnap from Brauron is at 4.145 and (in more detail) 6.138. The symbolism of the procession is suggested by Susan Cole, Landscapes, Gender and Ritual Space (Berkeley: University of California Press, 2004), pp. 228-30.

49. See e.g., Sarah Pomeroy, Goddesses, Whores, Wives and Slaves (New York: Schocken, 1975), p. 79. A similar point has been made in relation to other societies, both contemporary and historical; see e.g., Loosley, this volume, in relation to seventeenth-century Iran.

50. As in northern Nigeria: Pat Williams, 'The Impact of Islam on Women in Hausaland and Northern Nigeria', in Adebayo Oyebade (ed.), The Foundations of Nigeria: Essays in Honor of Toyin Falola (Trenton, NJ and Asmara: Africa World Press, 2003), pp. 591-621, esp. p. 603.

51. See Lloyd Llewellyn-Jones, Aphrodite's Tortoise (Swansea: Classical Press of Wales, 2003) for veiling, with pp. 189-214 for veiling as a route to increased mobility through public space.

52. In modern Greek villages during the mid-twentieth century, this strategy was observed as a means for women to escape censure for moving about too much in the public sphere. See Jill Dubisch, "Foreign Chickens" and Other Outsiders: Gender and Community in Greece', American Ethnologist 20 (1993), pp. 272-87, here p. 275.

53. This conclusion supports and expands the argument of Matthew Dillon, based on an extensive review of the evidence for female participation in Greek religion, that 'there were two rival social structures or systems ... [actual] practices and male ideas about women (at least expressed in the literary sources) were in some sense in opposition to each other'. Dillon, Girls and Women, p. 296.

54. As e.g., in Aristophanes' Peace, 981-2.

55. See e.g., Helen Watson, Women in the City of the Dead (London: Hurst, 1992), pp. 5-6 on women from Cairo's City of the Dead; Williams, 'Impact of Islam', p. 602 on women in northern Nigeria.

56. For male-female collusion, see Dubisch 'Foreign Chickens', p. 274 with further references. On crosscultural research, see Roland Fletcher, 'Materiality, Space, Time and Outcome', in John Bintliff (ed.), A Companion to Archaeology (London: Routledge, 2004), pp. 110-40, esp. p. 120.

57. I. Nevett, Domestic Space, pp. 22-42. Others have argued that these changes took place at a much earlier date. See e.g., Ian Morris, 'Remaining Invisible: The Archaeology of the Excluded in Classical Athens', in Sandra Joshel (ed.), Women and Slaves in Greco-Roman Culture (London: Routledge, 1998), pp. 203-20; Alexandra Coucouzeli, 'Architecture and Social Structure in Early Iron Age Greece', in Westgate, Fisher and Whitley (eds), Building Communities, pp. 169-82.

58. Dillon, Girls and Women, pp. 15-17.

59. Llewellyn-Jones, Aphrodite's Tortoise, p. 316.

60. Hoepfner and Schwandner, Haus und Stadt; Nevett, House and Society in the Ancient Greek World (Cambridge: Cambridge University Press, 1999), pp. 80-153. 